\title{
Noilguma noteikšanas problemātika apdrošināšanas attiecībās
}

\author{
Jeḷena Alfejeva \\ Rīgas Stradiña universitāte, Juridiskā fakultāte, Latvija \\ alfejeva@inbox.lv
}

\section{Kopsavilkums}

Raksts veltīts aktuālam tematam - noilguma noteikšanai Latvijas tiesībās, apskatot noilgumu attiecībā uz privāto apdrošināšanu. Tiesību normu saturs un to piemērošanas prakse rāda, ka apdrošināšanas attiecībās ir noilguma noteikšanas problēmas, kas saistītas ar neskaidru noilguma regulējumu dažādos tiesību aktos.

Lai gan komercdarbībā, it īpaši apdrošināšanā, komersantam svarīgi ir apzināties savas saistības reālā laikā, tomēr jautājums par noilgumu Latvijas tiesībās nevar tikt viennozīmīgi risināts. N̦emot vērā, ka uz dažādiem saistību pamatiem tiek noteikti krasi atšḳirīgi noilguma termiṇi, turklāt ar subjektīvi izmantojamām iespējām tos pārtraukt, svarīgi ir pievērsties šã jautājuma risināšanai. Minētā dēl jāpievērš lielāka uzmanība arī jautājumam par saistību pamatiem, lai pareizi noteiktu noilgumu saistību (prasības) tiesībām.

Raksta mērkis ir apdrošināšanas attiecībās izpētìt tiesību normas, kurās noteikts noilgums, kā arī apskatìt šo normu piemērošanas praksi un, pamatojoties uz to, ieteikt problēmu risināšanas iespējas.

Darba izstrādē tika izmantotas vispārējās zinātniskās un speciālās juridiskās izziṇas metodes: analīzes un sintēzes metode, zinātniskās indukcijas un dedukcijas metode, salīdzinošā un novērošanas metode. Pētījuma bāze ir dažādu dokumentu, atziṇu, viedokḷu un tiesību normu analīze (Civillikumā, Komerclikumā, likumā "Par apdrošināšanas līgumu" un Sauszemes transportlīdzekḷu ỉpašnieku civiltiesiskās atbildības obligātās apdrošināšanas likumā), kā arī novērošana.

Tiesību normu tulkošanai tika izmantota gramatiskā, vēsturiskā, sistēmiskā un teleolog̣iskā metode.

Pamatojoties uz pētījumu, tika formulēti priekšlikumi tiesiskā regulējuma pilnveidošanai apskatìtajā jomā.

Atslēgvārdi: apdrošināšana, noilgums. 


\section{levads}

Apdrošināšanas pakalpojumu sniegšana ir komercdarbības veids: tajā klients maksā apdrošinātājam (komersantam) atlīdzību par riska iestāšanās finansiālo seku pārṇemšanu (Apdrošināšanas un pārapdrošināšanas likuma 1. panta 9. punkts [1]), kas veido apdrošināšanas pakalpojumu. Apdrošināšanas pakalpojumi tiek sniegti par atlīdzību apdrošināšanas prēmiju -, par to vienojoties apdrošināšanas līgumā.

Kaut arī primārais tiesiskā regulējuma mērḳis ir nodrošināt, lai apdrošināšanai būtu pozitīvas sociālās sekas, tomēr tikpat svarīgi (arī primārā mērḳa nodrošināšanai) ir izveidot stabilu apdrošinātāju darbības tiesisko vidi. Komercdarbībā, kur cenu un darïjumu noteikumu noteikšana tiek istenota, pamatojoties uz sarežgìitiem aprēḳiniem, balstoties uz pagātnes datiem un nākotnes pieṇēmumiem, svarīgi ir zināt, kāds ir aktuālo saistību apjoms. Šajā ziņā būtiska loma ir noilguma institūtam.

Noilgums ir likumā noteikts termin̦š, pēc kura saistību tiesības izbeidzas, ja tiesīgā persona šìs tiesības pienācīgi neizlieto.

Vēl no romiešu tiesībām zināms ir noilguma jēdziens, kas ir būtiska Eiropas valstu tiesību sastāvdaḷa. Tas ir nepieciešams, lai nodrošinātu tiesisko attiecību stabilitāti un novērstu tādu prasību rašanos, kam pierādỉjumi nav ar sapratīgiem līdzekḷiem pārbaudāmi iesaistīto personu neskaidro atmiṇu, nāves vai līdzīgu apstākḷ dẹl.

Rūpējoties par tiesisko attiecību stabilitāti, likumdevējam arī svarīgi ir nesamazināt iespēju aizsargāt aizskartās tiesības ar tiesas palīdzỉbu, nosakot tik îsu laika periodu, ka personai nav iespējams uzsākt tiesvedību, izmantojot saprātīgos līdzekḷus. Tādējādi noilguma termiṇam jābūt noteiktam tādam, lai līdzsvarotu gan kreditora, gan parādnieka tiesiskās intereses.

N̦emot vērā minēto, šã raksta mērḳis ir identificēt tiesiskā regulējuma un juridiskās prakses problēmas ar noilguma noteikšanu apdrošināšanas attiecībās.

Izstrādē tika izmantotas vispārējās zinātniskās un speciālās juridiskās izziṇas metodes: analīzes un sintēzes metode, zinātniskās indukcijas un dedukcijas metode, salīdzinošā metode un vēsturiskā metode. Pētījuma bāze ir dažādu dokumentu, atziṇu, viedokḷu un tiesību normu analīze (Civillikumā, Komerclikumā, likumā "Par apdrošināšanas līgumu" un Sauszemes transportlīdzekḷu īpašnieku civiltiesiskās atbildības obligātās apdrošināšanas likumā), kā arī novērošana.

Tiesību normu tulkošanai tika izmantota gramatiskā, vēsturiskā, sistēmiskā un teleolog̣iskā metode. 


\section{Noilgums Latvijas civiltiesībās}

Civillikuma 1893. pantā noteikts, ka saistību tiesības izbeidzas, ja tiesīgā persona tās pienācīgi neizlieto likumā noteiktajā noilguma termiṇā [3].

Civillikuma 1895. pantā noteikts, ka visas saistību tiesības, kuras noteikti nav izṇemtas no noilguma ietekmes un kuru lietošanai likumā nav noteikts īsāks termiňš, izbeidzas, ja tiesīgā persona tās neizlieto desmit gadu laikā. Šajā normā noteikts, ka iespējami dažādi noilguma terminni, taču vispārējais ir desmit gadi. Tādējādi ar Civillikuma normām Latvijā tiek noteikts vispārējais saistību tiesību izlietošanas termiṇš, kas ir desmit gadi, kaut arī atsevišşos gadỉjumos likumā noteikts īsāks noilguma termiṇš [3]. Šādi gadījumi ietverti gan Civillikumā, gan arī citos likumos, piemēram, Komerclikumā $[3,4]$.

Tiesību doktrīnā norādīts, ka noilguma institūts civiltiesībās ir veidots, lai novērstu nenoteiktību mantiskajās attiecībās, radītu skaidrību situācijā, ja kāda persona ilgstoši neīsteno tiesības vai neprasa novērst iespējamo strīdu par tām. Nebūtu saprātīgi piel̦aut, ka iespējamais parādnieks uz mūžìgiem laikiem atrodas zem parāda atprasīšanas vai vismaz tiesāšanās Damokla zobena un nevar plānot savu darbību, izslēdzot šādus draudus [21, 276].

Tiesību doktrīnā arī norādīts, ka gadījumos, ja no saistības dalībniekiem kāds uzskata, ka viṇa tiesības ir aizskartas, viṇam ir tiesības celt prasību tiesā par tiesību atzīšanu vai aizskāruma seku novēršanu (lietas atdošanu, zaudējumu atlīdzību, līgumsoda samaksu).

Ja lietas izskatī̌̌anas gaitā tiesa konstatē, ka ir iestājies civiltiesību normās noteiktais noilgums, tā savā spriedumā norāda uz prasības noilgumu. To, vai iestājies noilgums, tiesa vērtē, tikai lietu izskatot pēc būtības, kurā pārbauda arī jautājumus par noilguma apturēšanu vai pārtraukšanu [21, 278].

Civillikuma 1902. pantā noteikts, ka tiesības izlietošana, ceḷot prasību tiesā vai griežoties pie škīinējtiesas, pārtrauc noilgumu, turklāt jau notecējušais laiks vairs nav ieskaitāms un sāk tecēt jauns noilguma termiṇš. Kaut arī vēršanās tiesā nepārprotami būtu uzskatāma par noilgumu pārtraucošu, neskaidrības rada Civillikuma 1905. panta pieminēšana, kad noilgumu tikpat vienkārši var pārtraukt ar kreditora atgādinājumu par parādu [3].

Aktuāls ir jautājums par noilguma terminu pēc pārtraukuma (tas vienmēr ir desmit gadi) - it īpaši, ja iepriekš noilguma termiņš bija îsāks ar likumdevēja īpaši tam noteikto mērki.

Rodas arī jautājums, vai prasības celšanai par līguma atcelšanu saskaṇā ar Civillikuma 1633. pantu [3], kur ir noteikts saīsināts noilgums, proti, seši mēneši, šo noilgumu iespējams pārtraukt ar kreditora atgādinājumu un vai pēc prasības celšanas, bet tālākas nevirzīšanas, noilgums būs desmit gadi. Tas, iespējams, būtu pretrunā ar saīsināta noilguma noteikšanas mērḳi - panākt tiesisko noteiktību sešu mēnešu laikā par līguma spēku. 
Arī citas Civillikuma normas rada jautājumus par to piemērošanu. Piemēram, 1904. pantā noteiktais [3] prasa pievērst uzmanību tam, vai prasības celšana par nokavējuma procentu samaksu par preču piegādi janvārī vai martā saskaṇā ar līgumu, kurš aptver katru mēnesi, pildāmas saistības sešu mēnešu periodā, nosakot izpildāmā apjomu, sortimentu un kvalitāti, dod pamatu uzskatìt, ka tiek pārtraukts arī noilgums strīdam par februārī piegādāto preču kvalitāti.

Redzams, ka likumdevējs Civillikumā ir paredzējis daudz veidu, kā iespējams noilgumu pārtraukt, un pēc pārtraukuma sāk tecēt jauns noilguma termiņš. Tas nozīmē, ka pietiekoši garais desmitgadīgais periods var tikt neierobežoti pagarināts, kas savukārt aktualizē jautājumu par noilguma noteikšanas mērḳu sasniegšanu. Tiesību izmantošana neierobežotā laika periodā var novest pie tā, ka parādsaistîbas tiek paildzinātas uz pārāk ilgu laiku un pierādījumu iesniegšana un to vērtēšana kḷust ievērojami apgrūtināta, jo liecinieki vairs neatceras, kas noticis pirms vairākiem gadiem, un daḷa pierādỉjumu ir pazudusi.

Iespējams, ka atsevišḳas Civillikuma normas, kas skar noilgumu, ir zaudējušas aktualitāti un nepieciešama to revīzija, tomēr šā raksta mērķis ir cits, tādēl lietderīgi ir apskatît noilguma reglamentāciju un piemērošanu apdrošināšanas attiecībās.

\section{Latvijas apdrošināšanas attiecību tiesiskā reglamentācija}

Latvijas tiesību sistēmā tiesisko darījumu vispārējā reglamentācija ir nodrošināta Civillikumā, bet speciālais komercdarījumu regulējums ietverts Komerclikumā. Taču apdrošināšanas līgums nav minēts nedz Komerclikumā, nedz Civillikumā.

Lai gan Civillikumā nav atsauces uz apdrošināšanas līgumu, tomēr tā normas par tiesiskajiem darỉjumiem attiecas uz apdrošināšanas līgumu kā uz vienu no saistību tiesībās regulētajiem līgumiem. Savukārt Komerclikums ir speciālais likums attiecībā pret Civillikumu, un tajā ir iekḷauta komercdarỉjumu tiesiskā reglamentācija. Komerclikuma 388. pantā paredzēts, ka komercdarījumi ir komersanta tiesiskie darïjumi, kas saistīti ar komercdarbību [4]. Saskaṇā ar Apdrošināšanas un pārapdrošināšanas likumā noteikto apdrošināšana ir viens no komercdarbības veidiem, apdrošinātājam sniedzot citām personām pakalpojumus par atlīdzību [1]. Savukārt Komerclikuma 389. pantā noteikts, ja darïjums ir komercdarïjums tikai vienam no darỉjuma dalïbniekiem, tad šã likuma noteikumi par komercdarījumiem ir vienlīdz piemērojami arī pārējiem darījuma dalībniekiem, ciktāl normatīvajos aktos patērētāju tiesību aizsardzības jomā vai citos likumos nav noteikts citādi [4].

Secināms, ka apdrošināšanas darījumu tiesiskais regulējums izriet no Komerclikuma un tikai pastarpināti - no Civillikuma, jo apdrošināšanas darījumi ir komercdarījumi un Komerclikums ir speciālais komercdarījumus reglamentējošais likums attiecībā pret Civillikumu. 
Apdrošināšanas darījumu tiesiskai reglamentācijai tika pieṇemts likums "Par apdrošināšanas līgumu" [7]. Tomēr šā likuma normas tika izveidotas atrauti no vispārējā darījumu tiesiskā regulējuma. Tāpēc grūti apdrošināšanas darỉjumiem piemērot līgumattiecības regulējošas vispārējās tiesību normas. Piemēram, šã likuma 6. panta otrajā daḷā ir noteikti nosacỉjumi, kas obligāti jāiekḷauj apdrošināšanas līgumā [7]. Savukārt Civillikuma normās tiek nošḳirtas darījumu sastāvdaḷas. Bez būtiskām sastāvdaḷām attiecīgā veida darījums nevar pastāvēt. Darỉjumā mēdz būt dabiskās sastāvdaḷas, kā arī nejaušās sastāvdaḷas, ko līgumā var iekḷaut papildus (piemēram, nosacījums - termiņšs). N̦emot vērā, ka apdrošināšanu reglamentējošās tiesību normās netiek paredzēta šāda darījuma struktūra, tiesību normu piemērošanā līdz šim bijušas problēmas. Piemēram, Latvijas Republikas Augstākās tiesas Civillietu departaments 2014. gada 12. marta spriedumā lietā Nr. SKC-184/2014 ir secinājis, ka apdrošināšanas prēmijas samaksa ir nebūtisks apdrošināšanas līguma nosacījums, jo ir līguma blakus nosacījums pretstatā nosacījumam par apdrošināšanas atlīdzības piedziṇu, kas savukārt ir būtisks līguma nosacījums [12]. Tādējādi apdrošināšanas līguma struktūrā kā pakalpojumu sniegšana par atlīdzību - apdrošināšanas prēmiju - nepamatoti tiek izcelta daḷa par pakalpojumu, savukārt pakalpojuma samaksu uztverot kā līguma blakus nosacỉjumu.

Apdrošinātāja saistības rodas tikai un vienīgi uz darījuma pamata - tas izriet gan no Eiropas Savienības tiesībām, gan arī jau atzîts Latvijas doktrīnā un judikatūrā. Tā Augstākās tiesas Civillietu departamenta prakses apkopojumā par sauszemes transportlīdzekḷu vadìtāju civiltiesiskās atbildības obligātās apdrošināšanas (OCTA) lietām (2016. gadā šis apkopojums tika publicēts Augstākās tiesas interneta vietnē, un pēc Augstākās tiesas pasūtijuma to sagatavoja Vadims Mantrovs) tiek paskaidrots, ka "apdrošināšanas tiesības ir viena no civiltiesību (privāttiesību) apakšnozarēm, kura aptver tiesiskas attiecības, kuras tiek dibinātas uz apdrošināšanas līguma pamata. Latvijas tiesas ir konsekventi klasificējušas apdrošināšanas līgumu kā saistību tiesību līgumu, norādot uz to, ka apdrošināšanas tiesības pieder pie saistību tiesībām, jo, noslēdzot līgumu, puses rada saistību attiecību, kurā nosaka katra dalïbnieka tiesības un pienākumus" [13, 7].

Tomēr šajā apkopojumā tā autors atrod apdrošināšanas attiecību saistību tikai ar Civillikumu kā vispārējo apdrošināšanas darījumus reglamentējošo tiesību aktu, Komerclikumu šajā sakarā nepieminot vispār.

Tas nozīmē, ka problēma ir izpratnē par to, kas īsti ir apdrošināšanas līgums.

\section{Noilgums Latvijas apdrošināšanas attiecībās}

N̦emot vērā, ka apdrošināšanas pakalpojumu sniegšana par atlīdzību ir viens no komercdarbības veidiem, saīsinātais noilgums, kas izriet no apdrošināšanas līguma saistībām, salīdzinot ar Civillikuma vispārējo noilgumu (desmit gadi), ir nepieciešams saskaṇā ar Komerclikuma grozījumu (stājās spēkā 2010. gadā) 406. pantā ieviesto saīsināto noilgumu komercdarijumiem $[5,18]$. 
Komercdarbïbas tiesiskais regulējums bez komercdarījumu daḷas tikai daḷēji atbilda Latvijas tiesībās pastāvošajai privāttiesību duālisma sistēmai. Komerctiesību galvenais uzdevums ir vienkāršot un paātrināt privāttiesisko (komerctiesisko) apgrozību, vienlaikus nodrošinot arī šīs apgrozības stabilitāti, paaugstinātu uzticības aizsardzību un komersantu atbildības pakāpi.

Šajā ziṇā nozīmīga loma ir tieši speciālajām tiesību normām, kuras regulē komercdarījumus, jo Civillikuma noteikumi nespēj pilnībā nodrošināt vienkāršību un ātrumu komercdarījumu noslēgšanā un izpildē.

Tādēḷ bija nepieciešama Komerclikuma D daḷa - speciālajam regulējumam darījumiem komerctiesībās vispārēji, to skaitā nosakot saīsināto noilguma termiṇu darījumiem.

Tagad Komerclikumā ir noteikts speciālais noilguma termiņš komercdarijumiem, proti, no komercdarïjuma izrietošie prasijjumi noilgst triju gadu laikā, ja likumā nav noteikts cits noilguma termin̦š. Tātad, n,emot vērā visu iepriekš minēto, jāsecina, ka uz apdrošināšanas darījumiem tāpat attiektos Komerclikumā noteiktais saīsinātais noilguma termiṇš (trīs gadi) gadījumā, ja kādā likumā nav noteikts cits noilguma termiṇš. Savukārt Civillikuma noteiktais vispārējais termiņš (desmit gadi) uz apdrošināšanas darījumu saistībām, sākot ar 2010. gadu, attiekties nevar.

Tomēr jāatzīmē, ka arī Komerclikuma normas par noilgumu apdrošināšanas attiecībām nebūtu jāpiemēro un jautājumu par noilguma speciālo regulējumu apdrošināšanas līgumā jārisina atbilstoši likumdevēja nodomam šā noilguma regulēšanai likumā "Par apdrošināšanas līgumu" [7].

Likuma "Par apdrošināšanas līgumu" spēkā esošās redakcijas 32. panta pirmajā daḷā ir noteikts termiņš apdrošināšanas gadījuma pieteikšanai apdrošinātājam. Savukārt šà panta otrajā daḷā noteikts: "Pārējās saistību tiesības, kas izriet no apdrošināšanas līguma, izbeidzas, ja persona tās neizmanto divu gadu laikā." [7]

Gramatiski tulkojot šo normu, jāsecina, ka:

1) speciālais termiṇš ir noteikts apdrošināšanas gadījuma pieteikšanai 32. panta pirmajā daḷā - palaižot garām šo termiṇu, pieteikt gadỉjumu vairs nav iespējams;

2) 32. panta otrajā daḷa ietvertā norma attiecas uz visām pārējām no apdrošināšanas līguma izrietošām saistību tiesībām - visām, kas nav paziṇojums par apdrošināšanas gadỉjumu, - gan tiesībām prasīt apdrošināšanas atlīdzības samaksu, gan arī prasìt apdrošināšanas prēmijas samaksu un citām;

3) visām pārējām no apdrošināšanas līguma izrietošām saistību tiesībām, kas nav pazinošana par apdrošināšanas gadījumu, tiek noteikts speciālais noilgums, t. i., divi gadi.

Savukārt Augstākās tiesas Civillietu departaments 2014. gada 12. marta spriedumā lietā Nr. SKC-184/2014, tulkojot minētās tiesību normas, norādīja, ka 32. panta otrajā daḷā noteiktais termin,šs, kurā izmantojamas līgumā ietvertās blakussaistības, nav attiecināms uz prasībām, kad apdrošinājuma nnēmējs vēršas pret apdrošinātāju nolūkā panākt saistības izpildi par apdrošināšanas atlīdzības izmaksāšanu, un ka atbilstoši vispārējai 
tiesību normai - Civillikuma 1895. pantam - šādu prasību noilgums ir desmit gadi, skaitot no dienas, kad apdrošinātājs atteicies izmaksāt apdrošināšanas atlīdzību [12].

Kaut arī sprieduma motīvu dal̦ā tika norādīts: "Atklājot pazīmes - pārējās saistību tiesības, kas izriet no apdrošināšanas līguma, - tvērumu, ir jāṇem vērā apdrošināšanas būtība" [12], tieši apdrošināšanas būtìba tiek uztverta un aprakstīta nepareizi. Apdrošināšanas līgums ir vienošanās par pakalpojumu sniegšanu par atlīdzību - apdrošinātājs sniedz pakalpojumus par līgumā noteikto apdrošināšanas prēmiju. Eiropas Savienības Tiesa vairākkārtīgi savos spriedumos ir secinājusi, ka apdrošināšanas darījumu raksturo apdrošinātāja pienākums, iepriekš iekasējot prēmiju, apdrošinātajai personai, ja ir iestājies apdrošināšanas gadījums, sniegt pakalpojumus, par kuriem ir panākta vienošanās, noslēdzot līgumu (sprieduma C-349/96 17. punkts, C-240/99 37. punkts un C-556/13 28. punkts) [9]. Tādējādi secinājums, ka apdrošināšanas prēmija ir blakus nosacījums, pielīdzināms tikpat nepareizam secinājumam, ka, piemēram, pirkuma maksa pirkuma līgumā nav būtisks līguma noteikums, bet ir tikai blakus noteikums.

Vērtējot Augstākās tiesas Civillietu departamenta spriedumā Nr. SKC-184/2014 minētās atziṇas, redzams, ka tiesa nepareizi atsaucās uz likuma "Par apdrošināšanas līgumu" grozịjumu projekta anotāciju, jo saskaṇā ar spriedumā norādītās anotācijas 2. daḷas (Normatīvā akta projekta būtība) 7. punktu, kas obligāti bija jālasa, interpretējot 32. panta otro daḷu pēc mērḳa, norādīts: "Izstrādātais likumprojekts maina prasījumu noilguma sistēmu personai, kurai ir tiesības pretendēt uz apdrošināšanas atlīdzību, paredzot, ka tiesības iesniegt apdrošinātājam paziņojumu par apdrošinātā riska iestāšanos izbeidzas, ja tās nav izmantotas triju gadu laikā no apdrošinātā riska iestāšanās dienas. Pārējās saistību tiesības, kas izriet no apdrošināšanas līguma, izbeidzas, ja persona tās neizlieto divu gadu laikā." [12]

Arī Finanšu un kapitāla tirgus komisijas darba grupa, formulējot minētos grozỉjumus, vadījās vienīgi no mērḳa noteikt saīsinātu noilgumu visām prasībām, kuras izriet no apdrošināšanas līguma, izṇemot paziṇošanu par apdrošināšanas gadījumu dzīvības un civiltiesiskās atbildības apdrošināšanas veidos, kas noteikta 32. panta pirmās daḷas pirmajā teikumā. Savukārt anotācijā norādītais par apdrošināšanas līguma vājāko pusi tika uzrakstīts vēlāk un skāra tikai jautājumu par apdrošinātāja tiesībām uz regresu - pēc tam, kad darba grupa bija formulējusi pārējos priekšlikumus, tostarp vēlāk grozijjumu tekstā iekḷauto Finanšu un kapitāla tirgus komisijas priekšlikumu 40. panta astoto daḷu izteikt šādi: "Apdrošinātājs ir tiesīgs izmantot savas tiesības uz regresa prasību trīs gadu laikā no apdrošināšanas atlīdzības izmaksas dienas” [6]. Izskatot likumprojektu Saeimā, lai novērstu atšḳirīgas attieksmes problēmas, tika atrisinātas arī nesaskaṇas starp Finanšu un kapitāla tirgus komisiju un Latvijas Apdrošinātāju asociāciju - 40. panta astoto dalı papildinot ar vārdiem "pret apdrošināto" [6].

Tādējādi, interpretējot likuma "Par apdrošināšanas līgumu" 32. panta otro dalı gan gramatiski, gan ṇemot vērā anotācijā norādīto mērḳi, - secināms, ka "pārējās saistību tiesības" ietver arī tiesības celt prasību par apdrošināšanas atlīdzỉbas piedziṇu. 
Jāpiemin, ka jautājumā par likuma "Par apdrošināšanas līgumu" 32. panta otro daḷu Augstākās tiesas Civillietu departaments vēlāk apstiprināja arī pretējo viedokli, ar 2016. gada 5. maija rīcības sēdes lēmumu civillietā Nr. C-30708612 norādot, ka apelācijas instances spriedumā noteikts, ka noilgums prasībai par apdrošināšanas atlīdzības piedziṇu ir divi gadi un tāpēc prasība ir noraidāma [14]. Tiesa nekonstatēja materiālo tiesību normu nepareizu piemērošanu, kas būtu novedusi pie lietas nepareizas izspriešanas, neierosinot kasācijas tiesvedỉbu.

Runājot par apdrošināšanas attiecību būtību un noilguma nozīmi civiltiesībās, ir skaidrs, ka apdrošinātāja darbības stabilitātei noilgums ir diezgan svarīgs [17]. Arī aț̣aujot celt prasību desmit gadu laikā, apdrošinātājam var tikt apgrūtināta iespēja pierādīt kādus apstākḷus, kas apdrošinātāju atbrīvo no apdrošināšanas līgumā noteikto saistību izpildes izṇēmuma gadỉjumā (kā tas ir noteikts likuma "Par apdrošināšanas līgumu" 24. pantā), kā arī uzliktu tam pārmērīgu slogu pierādījumu glabāšanai. Jāṇem arī vērā, ka Apdrošināšanas un pārapdrošināšanas likums uzliek apdrošinātājam pienākumu izveidot tā dēvētās tehniskās rezerves atbilstoši noslēgtajiem apdrošināšanas līgumiem un pārapdrošināšanai aprēķinātajām iespējamām apdrošinātāja saistībām. Lìdzko apdrošinātājs pieṇem lēmumu par apdrošināšanas atlīdzības atteikumu, attiecīgās rezerves tiek atbrīvotas. Ja tiek pieḷauts desmit gadu ilgs prasības noilgums, iespējama situācija, ka attiecīgo rezervju apdrošinātāja rīcībā nebūs, citiem vārdiem - iestāsies apdrošinātāja maksātnespēja. Turklāt apdrošinātājam kā komersantam ir noteikti darījumu dokumentu glabāšanas termiṇi un situācija, ka noilgums pārsniedz šos termiṇus, nebūtu piel̦aujama.

\section{Noilgums apdrošinātāja prasībai pret apdrošināto}

Likuma "Par apdrošināšanas līgumu" 40. pants 2007. gadā tika papildināts ar astoto daḷu [6], kurā noteikts, ka apdrošinātājs ir tiesīgs izmantot savas tiesības uz regresa prasību pret apdrošināto triju gadu laikā no apdrošināšanas atlīdzỉbas izmaksas dienas. Sākotnēji, likumu pieņemot, šāds termin,š netika noteikts, un toreiz likumā netika paredzēts saīsināts noilguma periods apdrošinātāja regresa prasījumu izlietošanai. Tieši šo regulējumu Augstākās tiesas Civillietu departaments novērtēja kā tādu, kas nostādīja apdrošinātāju nevienlīdzīgā (negodīgā) situācijā ar personu, kurai ir tiesības pretendēt uz apdrošināšanas atlīdzību, - salīdzinot to ar regulējumu šā likuma 32. panta otrajā dạ̦ā.

Nav šaubu, ka tieši persona, kurai ir tiesības pretendēt uz apdrošināšanas atlīdzību, ir apdrošināšanas darījuma vājākā puse. Tomēr, no vienas puses, likumdevēja risinājuma apšaubǐšana situācijā, kad normas gramatiskā interpretācija nel̦auj tiesību normu tulkot citādi (Civillikuma 4. pants), nevar tikt atzìta par normālu tiesas funkciju.

No otras puses, pievēršoties šo normu interpretācijai atbilstīgi mērḳim un sistēmiski, dažādi noteiktajiem termiṇiem iespējams atrast tādu izskaidrojumu, kas l̦auj 
saprast likumdevēja likumdošanas gribu. Šā likuma 40. panta astotās daḷas grozījumu sākotnējā redakcijā tika paredzēts, ka apdrošinātājs ir tiesīgs izmantot savas tiesības uz regresa prasību triju gadu laikā no apdrošināšanas atlīdzības izmaksas dienas. Panta pirmajā dạ̄ā noteikts, ka apdrošinātājs ar apdrošināšanas atlīdzības izmaksu pārn̦em apdrošinātā prasības tiesības pret personu, kas ir atbildīga par zaudējumiem, kuri veido izmaksāto apdrošināšanas atlīdzību. Tādējādi sākotnējā grozījumu redakcijā mēǵināts nepamatoti piešḳirt priekšrocības personai, kas piệāvusi prettiesisku rīcību, nodarot zaudējumus, un kas nav apdrošināšanas līguma dalībniece, jo uz šādu deliktatbildību attiecināms Civillikumā paredzētais noilgums - desmit gadi. Šādai atšḳirīgai attieksmei pret personu, kurai iestājusies deliktatbildība, atkarībā no tā, vai cietušais ir apdrošinājis savas mantiskās vērtības vai intereses, tiešām nav nekāda objektīvā pamatojuma.

Viedokli, ka grozỉjumiem nav objektīva pamatojuma, to izskatī̌sanas laikā pauda Latvijas Apdrošinātāju asociācija. N̦emot vērā Latvijas Apdrošinātāju asociācijas viedokli, 40. panta astotās daḷas redakcija tika papildināta ar vārdiem "pret apdrošināto" [6], tādējādi padarot šo noilgumu saistītu ar apdrošināšanas līgumu, radot problēmas to attiecināt uz deliktatbildību. Praksē gadās, ka, strādājot pie likuma grozījumu apstiprināšanas un meklējot kompromisa risinājumus izteiktajiem viedokḷiem, sistēmiskā analīze netika veikta, kas arī kḷuva par pamatu atšķirīgi noteiktajam noilguma termiṇam likuma "Par apdrošināšanas līgumu" 32. panta otrajā daḷā un 40. panta astotajā daḷā. Savukārt, ja 40. pants netiktu papildināts ar astoto daḷu, apdrošinātāja tiesībām uz regresa prasību pret apdrošināto attiektos tas pats noilguma termiņšs, kurš paredzēts 32. panta otrajā daḷā, - divi gadi. Tomēr šis pārpratums nekādā ziṇā nevar būt par pamatu, lai ignorētu šo saīsināto noilgumu [6].

Kopš likuma izmaiņu pieņemšanas jau pagājuši vairāki gadi, un par šo jautājumu tiesu praksē nenotika strīdi, izṇemot - par transportlīdzekḷ i îpašnieku civiltiesiskās atbildības apdrošināšanu, kur likumā noteiktajos gadījumos ir paredzēts regress pret apdrošināto [10, 11]. Šajā ziṇā būtu vērts apskatît, vai un kā likuma "Par apdrošināšanas līgumu" 40. panta astotajā dạ̦ā noteiktais noilgums ietekmē noilguma noteikšanu apdrošinātāja regresa tiesībām saskaṇā ar Sauszemes transportlīdzekḷ ì ipašnieku civiltiesiskās atbildības obligātās apdrošināšanas likumu, jo šīs tiesības ir pielīgtas pret apdrošinātajām personām, kuras ir līgumā norādītā transportlīdzekḷa ìpašnieks vai tā tiesīgie lietotāji (par to plašāk sk. nākamajā nodaḷā) [8].

Jāpiemin, ka risinājums, kurš novērstu neskaidrības par saīsināto noilgumu apdrošināšanas attiecībās, būtu likuma "Par apdrošināšanas līgumu" 32. panta otrajā dạ̦ā noteikto saistîbu tiesību noilguma terminu apdrošinātajiem - divus gadus - mainìt uz tikpat garu kā Komerclikumā, t. i., trīs gadiem. Šìs termiṇa izmaiṇas novērstu jebkuras nepamatotas interpretācijas un pasvìtrotu apdrošināšanas darījuma kā komercdarījuma dabu. 


\section{Sauszemes transportlīdzekḷu īpašnieku civiltiesiskās atbildības obligātās apdrošināšanas likumā noteiktais noilgums}

Sauszemes transportlīdzekḷu īpašnieku civiltiesiskās atbildības obligātās apdrošināšanas likumā (turpmāk arī - OCTA likumā), tāpat kā likumā "Par apdrošināšanas līgumu", ir normas par apdrošinātāja tiesībām uz regresa prasību. OCTA likuma 41. pantā noteikti tie gadījumi un personas, pret kurām apdrošinātājs un Latvijas Transportlīdzekḷu apdrošinātāju birojs var iesniegt regresa prasību. Taču noilgums šādām prasībām OCTA likumā nav paredzēts. Tādēḷ regresa prasības iesniegšanas noilguma termiṇš būtu jānosaka atbilstīgi likumam "Par apdrošināšanas līgumu", jo sauszemes transportlīdzekḷu īpašnieku civiltiesiskās atbildības obligātās apdrošināšanas līgums ir viens no apdrošināšanas līguma veidiem (visi apdrošināšanas veidi ir paredzēti Apdrošināšanas un pārapdrošināšanas likuma 19. pantā, bet iepriekš - Apdrošināšanas sabiedrību un to uzraudzības likuma 12. pantā) [1].

Tomēr pretēji tam Vidzemes apgabaltiesas Civillietu tiesas kolēgija 2014. gada 4. septembra spriedumā lietā Nr. C-33489513 secināja, ka "likums "Par apdrošināšanas līgumu" un attiecīgi arī minētā likuma 40. pants nav piemērojams attiecībām, kas izriet no OCTA apdrošināšanas, un attiecīgi arī nav piemērojams attiecībā uz OCTA likuma 41. pantā apdrošinātājam paredzētajām regresa prasībām, jo abu likumu pantiem ir atšķirīgs tvērums, tāpēc attiecībā uz noilguma termiṇu ir piemērojams Civillikuma 1895. pants, kas noteic, ka visas saistību tiesỉbas, kuras nav noteikti izṇemtas no noilguma ietekmes un kuru izlietošanai nav likumā noteikti isāki termiṇi, izbeidzas, ja tiesīgā persona tās neizlieto desmit gadu laikā." [16]

Problēmas noteikt OCTA likuma tvērumu ir vērojamas arī citos tiesu spriedumos, kas arī rada pamatu neskaidrībām tiesību normu izpratnē un piemērošanā [20, 567-583].

Jāatzīst, ka OCTA likuma tiesību normas nepiedāvā skaidru regulējumu noilgumam, tādēl tiesu praksē rodas pārpratumi.

OCTA likuma 31. pantā tiek noteikti arī zaudējumu atlīdzināšanas gadījumi ar noilgumu: ja cits apdrošinātājs vai Latvijas Transportlīdzekḷu apdrošinātāju birojs nodarītos zaudējumus ir atlīdzinājis, pirms apdrošinātājs, kurš apdrošinājis ceḷu satiksmes negadījumā zaudējumu nodarījušã transportlīdzekḷa īpašnieka civiltiesisko atbildību, pieṇēmis lēmumu par apdrošināšanas atlīdzības izmaksu, šis apdrošinātājs atlīdzina attiecīgajam citam apdrošinātājam vai Transportlīdzekḷu apdrošinātāju birojam šajā likumā noteiktajā kārtībā aprēḳinātās un izmaksātās atlīdzības summu. Prasību par zaudējumu atlīdzināšanu var pieteikt gada laikā no apdrošināšanas atlīdzības izmaksas dienas. Gadỉjumā, ja nodarītos zaudējumus saskaṇā ar brīvprātīgās apdrošināšanas līgumu ir atlīdzinājusi cita apdrošināšanas sabiedrība, apdrošinātājs, kurš apdrošinājis ceḷu satiksmes negadījumā zaudējumu nodarījušā transportlīdzekḷa īpašnieka civiltiesisko atbildību, vai Transportlīdzekḷu apdrošinātāju birojs (ja apdrošināšanas atlīdzība izmaksājama no Garantijas fonda) atlīdzina šajā likumā noteiktajā kārtībā aprēḳinātās un 
izmaksātās atlīdzības summu. Prasību par zaudējumu atlīdzināšanu var pieteikt gada laikā no apdrošināšanas atlīdzības izmaksas dienas [8].

Ar šo regulējumu tiek noteikti savstarpējo norēḳinu termiṇi apdrošinātājiem un Latvijas Transportlīdzekḷu apdrošinātāju birojam (par to gan ir bijušas neskaidrības attiecībā uz pārejas noteikumiem, kas nu, n,emot vērā pagājušo laiku no grozijjumu spēkā stāšanās, zaudējušas savu aktualitāti).

Savukārt OCTA likuma 38. pantā paredzēta apdrošināšanas atlīdzības pieprasīšanas kārtỉba, kurā noteikts, ka personai, kura pretendē sanememt apdrošināšanas atlīdzību par tās mantai nodarīto zaudējumu, tiesības celt prasību pret apdrošinātāju vai Latvijas Transportlīdzekḷu apdrošinātāju biroju izbeidzas, ja tās nav pieteiktas gada laikā no apdrošināšanas gadījuma iestāšanās. Savukārt personai, kura pretendē saṇemt apdrošināšanas atlīdzību par nodarīto veselības kaitējumu, tiesības celt prasību pret apdrošinātāju vai Latvijas Transportlīdzekḷu apdrošinātāju biroju izbeidzas, ja tās nav pieteiktas triju gadu laikā no apdrošināšanas gadījuma iestāšanās.

Šeit analīzei par noilgumu reglamentējošo tiesību normu piemērošanu svarīgi ir noteikt apdrošināšanas attiecību dalïbnieku saistỉbu pamatus.

Lai veiktu analīzi, vispirms jāidentificē cietušā, apdrošinātā un apdrošinātāja saistību pamati. Civillikuma 1402. pantā noteikts, ka saistību tiesības rodas vai nu no tiesiska darījuma, vai no neatḷautas darbỉbas, vai pēc likuma.

Tiesības uz zaudējumu atlīdzību konkrētajā gadījumā pastāv saistībā ar ceḷu satiksmes negadījumu - deliktu, kura izraisītājs (apdrošinātais) atbild par cietušajai trešajai personai nodarìtajiem zaudējumiem uz delikta pamata.

Tāpēc delikts ir tā tiesiskā attiecība, kuras ietvaros rodas prasỉjuma tiesības ceḷu satiksmes negadỉjumā cietušajam pret zaudējumu nodarītāju.

N̦emot vērā, ka apdrošinātājs ir komersants, kas veic apdrošināšanas komercdarbỉbu, sniedzot pakalpojumus par atlīdzību, tas saistības uzṇemas uz līguma pamata. Tādējādi apdrošinātāja saistību pamats ir līgums. Savukārt cietušais ir tiesīgs pieprasīt vinamam nodarìto zaudējumu atlīdzināšanu no personas, kas ir atbildīga par šiem zaudējumiem, t. i., no ceḷu satiksmes negadījumu izraisījušā transportlīdzekḷa īpašnieka vai tiesīgā lietotāja [2, 3], un tikai tāpēc, ka šis īpašnieks vai tiesīgais lietotājs savu civiltiesisko atbildību par šiem zaudējumiem ir apdrošinājis, cietušajam tiek pielīgtas tiesības prasît zaudējumu atlīdzināšanu apdrošinātājam, tomēr nepārsniedzot apdrošinātāja piešḳirtās apdrošināšanas aizsardzības apjomu pat tad, ja prasība par zaudējumiem pret nodarītāju viṇam ir par lielāku summu. Negadījuma izraisītāja atbildība nepāriet uz apdrošinātāju, bet apdrošinātājs tikai ar līguma noslēgšanu uzṇemas ar līguma noteikumiem ierobežotajā apmērā veikt maksājumus cietušajam negadījuma izraisītāja vietā.

Savukārt Latvijas Transportlīdzekḷu apdrošinātāju birojs no speciāla apdrošinātāju izveidota Garantijas fonda nodarìtos zaudējumus cietušajam atlīdzina tad, kad apdrošināšanas līgums šo zaudējumu segšanai nevar tikt izmantots, piemēram, līgums nav noslēgts (OCTA likuma 51. pants). Tādējādi negadījuma izraisìtājs vēl joprojām ir atbildīgs 
par visiem cietušajam nodarītajiem zaudējumiem, tomēr, lai cietušajam zaudējumu atlīdzināšanas procedūru padarìtu pēc iespējas efektīvāku, likumā noteikts, ka Latvijas Transportlīdzekḷu apdrošinātāju birojs zaudējumus sedz pats un vēlāk pieprasa visu iztērēto naudas summu no personas, kas atbildīga par zaudējumiem. Tas arī nekādā veidā nepārveido transportlīdzekḷa īpašnieka civiltiesisko atbildību, kas ir paredzēta ar Civillikuma normām un Cel̦u satiksmes likuma 44. pantu [2, 3].

N̦emot vērā apdrošinātāja saistību līgumisko dabu, prasībām atbilstīgi apdrošināšanas līgumam, t. i., prasībām pret apdrošinātāiem būtu piemērojams noilguma termiņš, kurš apdrošināšanas līgumā ir noteikts saistībām.

Savukārt Latvijas Transportlīdzekḷu apdrošinātāju birojam saistības tiek noteiktas ar OCTA likumu, tādējādi noilgums būtu piemērojams atbilstīgi tam, bet, ja tas nav noteikts, tad kā vispārējais Civillikumā paredzētais noilgums.

Lietā Nr. C-30621216 pirmās instances tiesa spriedumā gan noteica saistību tiesību rašanās pamatus kḷūdaini, uzskatot, ka prasitāja prasības tiesības pret apdrošinātāju izcel̦as uz likuma pamata, nevis uz delikta vai lïguma (komercdarijuma) pamata [15]. No šā kḷūdainā tiesas secinājuma izriet arī turpmākās analīzes nepareizība, kas noved līdz nepareiziem gala secinājumiem, apmierinot prasību situācijā, kad bija iestājies noilgums apdrošinātāja saistību tiesībām.

Situāciju šajā civillietā sarežǵìja apstāklis, ka prasītājs bija Nacionālais veselības dienests, kas ir iestāde, kura apmaksāja cietušā ārstēšanās izdevumus.

Arī iestādes prasība pret apdrošinātāju tiek atvasināta no zaudējumu atlīdzināšanas prasības, kas izriet no ceḷu satiksmes negadījuma izraisī̌nanas kā tādas - iestāde tikai pārṇem no cietušā tiesības prasīt zaudējumu atlīdzināšanu no personas, kas ir atbildīga par zaudējumu izraisīšanu. Pretējā gadījumā apdrošinātājam nebūtu pienākums veikt apdrošināšanas atlīdzības maksājumus saskaṇā ar transportlīdzekḷa īpašnieka vai tā tiesīgā lietotāja civiltiesiskās atbildības apdrošināšanas līgumu.

Tas, ka prasītājs nav konkrētā apdrošināšanas līguma dalībnieks, nemaina apdrošinātāja saistību rašanās pamatu.

OCTA likuma 24. panta pirmajā dạ̦ā iekḷautajā regulējumā paredzēta valsts budžeta un pašvaldību budžetu izdevumu atlīdzināšana par līdzekḷiem, kas iztērēti cietušā stāvokḷa atjaunošanai saistībā ar negadỉjumu, un tas nevar mainìt saistību rašanās pamatu prasītājam - deliktu; tiek tikai pārṇemtas cietušā tiesības uz zaudējumu atlīdzību pret atbildīgo, kas pastāvēja pašam cietušajam.

Tiesa spriedumā nenēema vērā, ka tiesību normas, kurās noteikts tiesisko attiecību saturs delikta vai darījuma gadỉjumā, tomēr pašas par sevi nav saistību rašanās pamats. Nevar vērtēt, piemēram, šādi: ja Civillikumā norādīts, ka delikta rezultātā nodarītais zaudējums ir jāatlīdzina (1775. pants), tad šajā gadïjumā saistību rašanās pamats ir Civillikums, nevis konkrētais delikts. Turklāt, piemēram, apstāklis, ka pirkuma līguma regulējums Civillikuma 2033. pantā paredz, ka pircējam ir jāsamaksā pirkuma maksa, nedod pamatu uzskatīt, ka pircēja saistību pamats pret pārdevēju par pirkuma maksas samaksu izriet no Civillikuma, nevis no konkrētā pirkuma līguma. 
Šajā gadījumā tiesas nepareizais secinājums spriedumā par saistību rašanās pamatu nedeva iespēju tālāk apspriest jautājumu par Komerclikuma 406. pantā paredzēto noilgumu saistību tiesībām, kas izriet no komercdarījuma, vai arī likuma "Par apdrošināšanas līgumu" 32. panta otrajā dạ̦ā paredzēto noilgumu saistību tiesībām, kas izriet no apdrošināšanas līguma. Tāpat bez vērtēšanas palika arī OCTA likuma 38. pantā paredzētais terminš̌ prasības celšanai pret apdrošinātāju.

Pamatojoties uz veikto analīzi, secināms, ka situācijas vienkāršošanai būtu jāveic tiesību normu grozījumi, nosakot vienādu noilguma terminu gan atlīdzības pieteikšanai, gan prasības celšanai, un šis noilgums būtu trīs gadi, tādējādi šo termin̨u pielīdzinot noilgumam, kas paredzēts gan Komerclikumā, gan likumā "Par apdrošināšanas līgumu".

\section{Secinājumi un priekšlikumi}

Pamatojoties uz veikto analīzi, secināms, ka noilgums apdrošināšanas attiecībās ir noregulēts atšķirīgi un neskaidri virknē dažādus tiesību aktus (likumu "Par apdrošināšanas līgumu", Komerclikumu, OCTA likumu) un to savstarpējā korelācija un atšķirīgais skaidrojums no gramatiskā viedokḷ šobrīd rada problēmas tiesību normu piemērošanai praksē.

Viena no noilguma regulējuma problēmām apdrošināšanas attiecībās ir dažādie noilguma terminin:

1) likuma "Par apdrošināšanas līgumu" 32. panta pirmajā daḷā noteikts, ka tiesības iesniegt apdrošinātājam paziņojumu par apdrošinātā riska iestāšanos izbeidzas, ja persona, kurai ir tiesības pretendēt uz apdrošināšanas atlīdzību par dzīvības un civiltiesiskās atbildības apdrošināšanu, tās neizmanto 10 gadu laikā no apdrošinātā riska iestāšanās dienas, bet pārējos apdrošināšanas veidos - triju gadu laikā no apdrošinātā riska iestāšanās dienas;

2) likuma "Par apdrošināšanas līgumu" 32. panta otrajā dal̦ā noteikts, ka pārējās saistību tiesības, kas izriet no apdrošināšanas līguma, izbeidzas, ja persona tās neizmanto divu gadu laikā;

3) likuma "Par apdrošināšanas līgumu" 40. panta astotajā daḷā noteikts, ka apdrošinātājs ir tiesīgs izmantot savas tiesības uz regresa prasību pret apdrošināto triju gadu laikā no apdrošināšanas atlīdzības izmaksas dienas;

4) OCTA likuma 38. panta trešajā daḷā noteikts, ka personai, kura pretendē saņemt apdrošināšanas atlīdzību par tās mantai nodarìto zaudējumu, tiesības celt prasību pret apdrošinātāju vai Latvijas Transportlīdzekḷu apdrošinātāju biroju izbeidzas, ja tās nav pieteiktas gada laikā no apdrošināšanas gadījuma iestāšanās;

5) OCTA likuma 38. panta ceturtajā dal̦ā noteikts, ka personai, kura pretendē saṇemt apdrošināšanas atlīdzību par nodarìto veselïbas kaitējumu, tiesības celt prasību pret apdrošinātāju vai Latvijas Transportlīdzekḷ̣u apdrošinātāju biroju izbeidzas, ja tās nav pieteiktas triju gadu laikā no apdrošināšanas gadījuma iestāšanās. 
No iepriekšējas analīzes un starptautiskās pieredzes [19, 976] izriet šādas atziṇas:

1) apdrošināšanas līgums ir komercdarījums, tāpēc to reglamentējošo likumu hierarhija būtu šāda: Civillikums, Komerclikums, likums "Par apdrošināšanas līgumu", OCTA likums;

2) noilgums ir paredzēts gan vispārējās tiesību normās, gan speciālajās tiesību normās;

3) pareiza pieeja apdrošināšanas līgumu reglamentējošo tiesību normu veidošanai novērsīs izveidojušās problēmas tiesību normu interpretācijā tiesu praksē un laus sabiedrībai izmantot visas iespējamās apdrošināšanas priekšrocības.

Lai novērstu problēmas ar noilguma piemērošanu apdrošināšanas attiecībās, nepieciešams veikt grozījumus tiesību aktos.

Ir jāgroza likuma "Par apdrošināšanas līgumu" 32. panta otrā daḷa, izsakot to šādā redakcijā: "Pārējās saistību tiesības, kas izriet no apdrošināšanas līguma un nav noregulètas ar šā panta pirmo daḷu, izbeidzas, ja persona vai apdrošinātājs tās neizmanto trīs gadu laikā."

Priekšlikums ir OCTA likuma 38. panta trešo dalı izteikt šādā redakcijā: "Personai, kura pretendē saṇemt apdrošināšanas atlīdzību par tās mantai nodarìto zaudējumu, tiesības celt prasību pret apdrošinātāju vai Transportlīdzekḷu apdrošinātāju biroju izbeidzas, ja tās nav pieteiktas triju gadu laikā no apdrošināšanas gadījuma iestāšanās."

Savukārt OCTA likuma 38. pantu būtu lietderīgi papildināt ar 4. ${ }^{1}$ daḷu: "Visas saistību tiesības, kas izriet no apdrošināšanas līguma un pieder apdrošinājuma nēēējam, apdrošinātajam, apdrošinātājam vai jebkurai trešajai personai un jebkuram tās saistību pārnēēmējam, izbeidzas, ja tiesīgā persona tās pienācīgi neizlieto trīs gadu laikā. Brīdis, no kura sāk tecēt šis noilgums, izṇemot šā panta trešajā un ceturtajā daḷā paredzēto, nosakāms atbilstoši Civillikuma 1896. pantam."

Tāpat OCTA likuma 38. pantu varētu papildināt ar šādu 4. ${ }^{2}$ daḷu: "Visas saistību tiesības, kas pieder cietušajam vai jebkuram tās saistību pārṇēmējam, prasìt zaudējumu atlīdzību no Transportlīdzekḷu apdrošinātāju biroja šajā likumā paredzētājos gadījumos, izbeidzas, ja tiesīgā persona tās pienācīgi neizlieto trīs gadu laikā. Brīdis, no kura sāk tecēt šis noilgums, izṇemot šã panta trešajā un ceturtajā daḷā paredzēto, nosakāms atbilstoši Civillikuma 1896. pantam."

\section{Issues of Determination of Period of Limitation of Obligations in Insurance Relations}

\section{Summary}

The article is devoted to the topical subject - the limitation period under Latvian law, looking at it in relation to private insurance. Contents of legislative provisions and practice of their application show that the insurance concerning the limitation period is problematic because of obscure limitation rules in different legal acts. 
Despite the fact that in trade in general and insurance in particular, it is important to be aware of their obligations in real time, the issue of limitation in Latvian law cannot be clearly addressed. Given that for the various commitments, dramatically different limitation periods are set, as well as the possibilities for a person to stop, it is important to address the issue. In order to correctly determine the limitation commitments (requirements) rights should be given more attention.

The article aims to explore the legal provisions governing the limitation of insurance relations, as well as look at these provisions in practice, on the basis of which to determine the problem-solving capabilities.

General scientific methods are used, as well as special legal investigation methods analysis and synthesis methods, inductive and deductive methods, comparative method and method of observation. The research is based on various documents, ideas, opinions and points of law in the Civil Law, Commercial Law, the Law on the insurance contract and the Motor Third Party Liability Insurance Act analysis, as well as observation.

Grammatical, systematic and teleological methods are used for interpretation of legal norms.

Research proposals are formulated at the end of the legal framework for improvement of the field covered.

Keywords: insurance, period of limitation of obligations. Apdrošināšanas un pārapdrošināšanas likums: Latvijas Republikas likums. Latvijas Vēstnesis. 124, 30.06.2015.

\section{Avoti un literatūra}

\section{Tiesibu akti}

1. Cel̦u satiksmes likums: Latvijas Republikas likums. Latvijas Vēstnesis. 274/276 (989/991), 21.10.1997; Ziñotājs. 22, 27.11.1997.

2. Civillikums: Latvijas Republikas likums. Valdïbas Vēstnesis. 41, 20.02.1937.

3. Komerclikums: Latvijas Republikas likums. Latvijas Vēstnesis. 158/160, 04.05.2000.

4. Likumprojekta "Grozījumi Komerclikumā" anotācija. No: titania.saeima.lv 05.09.2007. Iegūts no: http://titania.saeima.lv/LIVS/SaeimaLIVS.nsf/0/CA622B7AA262009CC225736B004CD A92?OpenDocument\#_ftn9 [sk. 02.03.2017.].

5. Likumprojekta "Grozījumi likumā "Par apdrošināšanas līgumu"” anotācija. No: titania. saeima.lv 12.09.2006. Iegūts no: http://titania.saeima.lv/LIVS/SaeimaLIVS.nsf/0/06A456D0 84843358C225724.4004.A2052 [sk. 05.03.2017.].

6. Par apdrošināšanas līgumu: Latvijas Republikas likums. Latvijas Vēstnesis. 188/189, 20.06.1998.

7. Sauszemes transportlīdzekḷu îpašnieku civiltiesiskās atbildības obligāāās apdrošināšanas likums: Latvijas Republikas likums. Latvijas Vēstnesis. 65(3013), 27.04.2004.; Ziñotājs. 10, 29.04.2004.

8. Eiropas Savienības Tiesas (ceturtā palāta) 2015. gada 26. marta spriedums (Lietuvos Aukščiausiasis Teismas (Lietuva) lūgums sniegt prejudiciālu nolēmumu) - "Litaksa" UAB / “BTA Insurance Company" SE (lieta Nr. C-556/13), 25.1.2014. 
Jel̦ena Alfejeva. Noilguma noteikšanas problemātika apdrošināšanas attiecībās

\section{Tiesu prakse}

9. Jelgavas tiesas 2014. gada 10. februāra spriedums lietā Nr. C-15249813. Iegūts no: https:// www.tiesas.lv/nolemumi/pdf/151337.pdf [sk. 03.03.2017.].

10. Jelgavas tiesas 2015. gada 18. marta spriedums lietā Nr. C-15188814. Iegūts no: https://www. tiesas.lv/nolemumi/pdf/210630.pdf [sk. 03.03.2017].

11. Latvijas Republikas Augstākās tiesas Civillietu departamenta 2014. gada 12. marta spriedums lietā Nr. SKC-184/2014. Iegūts no: http://at.gov.lv/files/files/skc-184-2014.docx [sk. 03.03.2017.].

12. Latvijas Republikas Augstākās tiesas Civillietu departamenta prakses apkopojums sauszemes transportlīdzekḷu vadītāju civiltiesiskās atbildības obligātās apdrošināšanas (OCTA) lietās. No: Latvijas Republikas Augstākā tiesa, 2015. Iegūts no: www.at.gov.lv [sk. 03.03.2017.].

13. Latvijas Republikas Augstākās tiesas Civillietu departamenta rīcības sēdes 2016. gada 5. maija lēmums lietā Nr. C-30708612. Nepublicēts.

14. Ventspils tiesas 2016. gada 12. decembra spriedums lietā Nr. C-30621216.

15. Vidzemes apgabaltiesas Civillietu tiesas kolēǵijas 2014. gada 4. septembra spriedums lietā Nr. C-33489513. Iegūts no: https://www.tiesas.lv/nolemumi/pdf/185587.pdf [sk. 03.03.2017].

\section{Literatūra}

16. Alfejeva, J., Cielava, V. Likums jāpiemēro tādā nozīmē, kādu domājis likumdevējs. Jurista Värds. 15, 14.04.2015.

17. Balodis, K. Ieteicamais komercdarïumu regulējums Komerclikumā. Likums un Tiesïbas. 8, 02.03.2004.

18. Principles of European Insurance Contract Law (PEICL). Ed. by J. Basedow, J. Birds, M. A. Clarke, H. Cousy, H. Heiss, L. D. Loacker. Köln: Otto-Schmidt, 2016.

19. Torgāns, K. Regresa prasība OCTA apdrošināšanā. No: Civiltiesību, komerctiesību un civilprocesa aktualitātes: raksti, 1999-2008. Rīga: Tiesu namu ağentūra, 2009.

20. Torgāns, K. Saistību tiesības. I daḷa. Mācību grāmata. Rīga: Tiesu namu ag̉entūra, 2006. 